\title{
Synthesis and evaluation of diphenol aldimines as inhibitors of Escherichia coli ATPase and cell growth
}

\author{
Zulfiqar Ahmad ${ }^{1}$, Prasanna K. Dadi ${ }^{2}$, Jesse Elord ${ }^{2}$, Ismail O. Kady ${ }^{2}$ \\ ${ }^{1}$ Department of Biological and Environmental Sciences, Alabama A\&M University, Normal, USA \\ ${ }^{2}$ Department of Chemistry, East Tennessee State University, Johnson City, USA \\ Email: "kadyi@etsu.edu
}

Received 18 October 2011; revised 18 December 2011; accepted 25 December 2011

\begin{abstract}
A series of structurally related diphenol aldimines (DPAs) were synthesized. These aldimines involve different substitution patterns of their phenolic groups, for the purpose of optimizing their ability to inhibit ATP synthase. The inhibitory effects of these DPA compounds were evaluated using purified $F_{1}$ and membrane-bound $F_{1} F_{0} E$. coli ATP synthase. Structure-activity relationship studies of these diphenol compounds showed that maximum inhibition was achieved when both phenolic groups are either in the meta-positions (DPA-7, $\mathrm{IC}_{50}=\mathbf{2 . 0} \boldsymbol{\mu M}$ ), or in the ortho-positions (DPA-9, $\left.\mathrm{IC}_{50}=5.0 \mu \mathrm{M}\right)$. The lowest ATP synthase inhibition was found to be when the phenolic groups are both in the para-positions (DPA-2, $\mathrm{IC}_{50}=$ $100.0 \mu \mathrm{M})$. Results also show that the inhibitory effects of these compounds on ATPase are completely reversible. Identical inhibition patterns of both the purified $F 1$ and the membrane bound $F_{1} F_{0}$ enzyme were observed. Study of $E$. coli cell growth showed that these diphenol aldimines effectively inhibit both ATP synthesis and cell growth.
\end{abstract}

Keywords: Aldimine; ATPase; ATP Synthase; Diphenol; Polyphenol; Enzyme Inhibition; E. coli

\section{INTRODUCTION}

ATP synthase, the last enzyme of the oxidative phosphorylation in the respiratory chain, catalyzes the synthesis of ATP by oxidative phosphorylation of ADP. It is described as a "molecular motor" that is driven by the electrochemical gradient of protons and sodium ions across the mitochondrial membrane. For recent reviews of ATP synthase, see [1-4]. Recently it has been shown that ATP synthase or its components, found on the outer surface of plasma membrane, can function as a receptor for various ligands and plays an important role in the immune response of tumor cells [5-9]. It has been also

\footnotetext{
"Corresponding author.
}

reported that elevated expression of ATP synthase on endothelial cell surfaces plays a critical role in cellular processes during angiogenesis; thus the action of the angiogenesis inhibitor angiostatin can be in part attributed to inhibition of ATP synthase [10]. ATP synthase also plays a pivotal role in the general health of living cells. Abnormalities in the function of this enzyme have been associated with a number of human diseases that are linked to mitochondrial myopathy, such as diabetes, heart disease, and cancer.

Several unregulated proteins have been recently identified in cancerous tissues, including ATP synthase which was found to be expressed at high levels in the breast tumor tissues [11]. This was contrary to the common belief that $\mathrm{F}_{1} \mathrm{~F}_{0}$ ATP synthase is expressed only in mitochondria where most of the cellular ATP synthesis takes place. Other reports have shown that ATP synthase is expressed in the extracellular surface of endothelial cells in some tumor tissues; however, its function with regard to cancer development is still not clear [12-14]. The antibiotic Aurovertin B is reported recently to have remarkable inhibitory effects on ATP synthase and on the proliferation of cancer cells; it is currently under investigation for treatment of breast cancer [11]. Glick and coworkers have also observed that 1,4-benzodiazepine (BZ-423) inhibits ATP synthase by binding to the oligomycin sensitivity-conferring protein subunit of the mitochondrial $\mathrm{F}_{1} \mathrm{~F}_{0}$, causing significant decrease in ATP synthesis and significant increase in production of superoxide which activates redox-regulated apoptosis [15]. The role of ATP synthase in oxidative metabolism in tumor cells has been recently reviewed; it was proposed that energy metabolism may be used as an alternative therapeutic target for treatment of both hypoxic (glycolytic) and oxidative tumors $[16,17]$. Therefore, it is not surprising to see ATP synthase becoming a primary target for cancer therapies.

The inhibition of biofilm formation and acid production by $S$. mutans through the inhibition of proton-translocating F1-ATPase activity in presence of a variety of natural polyphenols $[18,19]$, and the involvement of $m y$ - 
cobacterium ATP synthase in conferring resistance against the anti-tuberculosis drug diarylquinoline [20], all indicate a strong need for more potent inhibitors of bacterial ATP synthase. It is evident from these studies that structural modification of polyphenols could provide a starting point to develop potent inhibitors against bacterial pathogens such as $S$. mutans and M. tuberculosis. Nevertheless, mutagenic analysis of polyphenols binding site residues should be the next step to advance the current understanding of the benefits of polyphenols in combating disease conditions.

There has been strong interest lately in evaluating the beneficial dietary effects of polyphenols not only as antioxidants that protect cells against free radical damage, but also for possible chemotherapeutic applications [21, 22]. It has been reported recently that the polyphenols resveratrol, piceatannol, and quercetin can inhibit both bacterial and mitochondrial ATP synthases [23-25], presumably by hindering the enzyme's rotary mechanism. However, the inhibitory concentrations of such polyphenols on molar scales are much higher than the desired levels for therapeutic purposes. Hence, in order to reap the full benefits of polyphenols physiologically, it is vital to identify more potent polyphenols inhibitors. The basic stilbene framework of polyphenols and the positions of their hydroxyl groups appear to be critical in exerting the inhibitory effect on ATP synthase [26]. Therefore, we embarked on the structural modification of polyphenols for the purpose of enhancing their ability to inhibit the $E$. coli ATP synthase and facilitating the development of antimicrobial and chemotherapeutic agents. Thus inhibitory studies of the wild-type and mutant E. coli ATP synthase by such polyphenols would divulge a wealth of information that could provide basis for development of new therapies for treating diseases like cancer and for combating pathogenic bacteria.
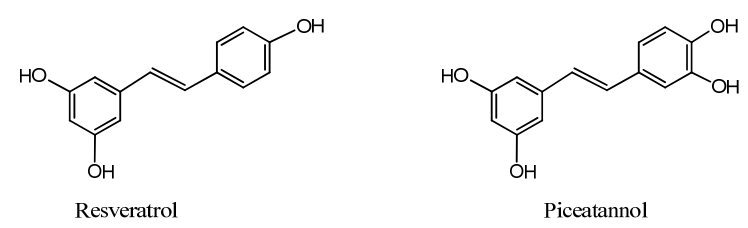

In order to explore the structure-activity relationship (SAR) of polyphenols we synthesized a series of diphenol aldimine (DPA) analogs of the natural polyphenols (Scheme 1), and studied their inhibitory effects on $E$. coli ATP synthase. These novel compounds have at least two structural advantages over the natural polyphenols. First, the higher polarity of the imine group, compared to the alkene group found in the natural polyphenols, makes these aldimines more water soluble, which improves their bioavailability and thus lowers their effective inhibitory concentrations. Second, replacing the carbon-

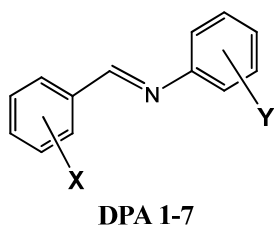<smiles>O=[N+]([O-])c1cc(O)ccc1/N=C/c1ccccc1O</smiles>

DPA-8<smiles>O=[N+]([O-])c1ccc(/N=C/c2ccccc2O)c(O)c1</smiles>

DPA-9

\begin{tabular}{|ccc|}
\hline Copmound & $\mathbf{X}$ & $\mathbf{Y}$ \\
\hline DPA-1 & $\mathrm{o}-\mathrm{OH}$ & $\mathrm{p}-\mathrm{OH}$ \\
DPA-2 & $\mathrm{p}-\mathrm{OH}$ & $\mathrm{p}-\mathrm{OH}$ \\
DPA-3 & $\mathrm{p}-\mathrm{OH}$ & $\mathrm{m}-\mathrm{OH}$ \\
DPA-4 & $\mathrm{o}-\mathrm{OH}$ & $\mathrm{o}-\mathrm{OH}$ \\
DPA-5 & $\mathrm{m}-\mathrm{OH}$ & $\mathrm{o}-\mathrm{OH}$ \\
DPA-6 & $\mathrm{o}-\mathrm{OH}$ & $\mathrm{m}-\mathrm{OH}$ \\
DPA-7 & $\mathrm{m}-\mathrm{OH}$ & $\mathrm{m}-\mathrm{OH}$ \\
\hline
\end{tabular}

Abbreviation: DPA-1: 2-[[(4-Hydroxyphenyl)imino]methyl]phenol; DPA-2 4-[[(4-Hydroxyphenyl)imino]methyl]phenol; DPA-3: 4-[[(3Hydroxy phenyl) imino]methyl]phenol; DPA-4: 2-[[(4-Hydroxyphenyl)imino]methyl]phenol; DPA-5: 3-[[(2-Hydroxyphenyl)imino]methyl]phenol; DPA-6: 2-[[(3Hydroxyphenyl) imino]methyl] phenol; DPA-7: 3-[[(3-Hydroxyphenyl)imino] methyl]phenol; DPA-8: 2-[[(4-hydroxy-2-nitrophenyl)imino]methyl] phenol; DPA-9: 2-[[(2-hydroxy-4-nitrophenyl)imino]methyl]phenol.

\section{Scheme 1}

carbon double bond of stilbene with isosteric imine group introduces an additional ligand-protein interaction which enhances the binding affinity of the aldimines to the enzyme. Additionally, at physiological $\mathrm{pH}$ the aldimine nitrogen would most likely be protonated to form iminium ion $\left(-\mathrm{CH}=\mathrm{NH}^{+}-\right)$which can cause additional electrostatic interaction in the enzyme's binding site. Introduction of a positive charge in the binding site will change not only the interaction but possibly the positioning or orientation of the aldimine inhibitors, which may influence the proton transfer mechanism of the enzyme.

\section{MATERIALS AND METHODS}

\subsection{General}

All reagents, including hydroxylbenzaldehydes and aminophenols starting materials, were purchased from Aldich Chemical Company (USA), and were either recrystallized for the proper solvents (if solids) or distilled under nitrogen atmosphere (if liquids). All solvents were purchased from Fisher Scientific and were distilled prior to use. Proton ${ }^{1} \mathrm{H}$ NMR and carbon- $13{ }^{13} \mathrm{C}$ NMR spectra were acquired on a $400 \mathrm{MHz}$ JEOL-Eclipse NMR spectrometer; all chemical shifts are recorded relative to tetramethylsilane (TMS) as an internal reference. Gas chromatography-mass spectra (GC-MS) were obtained 
on a Hewlett-Packard 5890 GC-MS. Melting points were obtained on a Mel-Temp apparatus, and were reported without correction.

\subsection{Synthesis of Diphenol Aldimines (DPAs)}

The diphenol aldimines were synthesized by the following two methods:

Method A: Equimolar amounts (1 mmole) of each of the aldehyde and the amine were mixed in a small glass flask and heated in a standard kitchen-style microwave oven for 3 - 5 minutes, after which the product was then recrystallized from aqueous ethanol.

Method B: Equimolar amounts (0.1 mole) of each of aldehyde and the amine were dissolved in $150 \mathrm{~mL}$ a solution containing absolute ethanol and benzene $(2: 1 \mathrm{v} / \mathrm{v})$ in a round-bottom flask equipped with a Dean-Stark receiver and a condenser. The solution was refluxed under $\mathrm{N}_{2}$ atmosphere while allowing water that is formed during the reaction to distill out. Reaction was stopped when no more water was observed in the azeotrope distillate, or when thin-layer chromatography (TLC) showed complete disappearance of the starting materials (typically 2 3 hours). The remaining solution was concentrated to 50 $\mathrm{mL}$ under reduced pressure, and the pure product was allowed to crystallize upon cooling.

\subsection{Assay of ATPase Activity}

$\mathrm{F}_{1}$ ATP synthase was isolated from the membrane of $E$. coli (wild type strain pBWU13.4/DK8) [27], and purified by following literature protocols [28]. The enzyme's activity was measured as in [29], in the presence or absence of inhibitors, at $37^{\circ} \mathrm{C}$ and $\mathrm{pH} 8.5$. Cell growth studies of the wild-type strain of E. coli were performed as in [30], on succinate plates or on limiting glucose at $37^{\circ} \mathrm{C}$, and in presence of $100 \mu \mathrm{M}$ of inhibitor.

\section{RESULTS AND DISCUSSION}

\subsection{Chemical Synthesis}

The diphenol aldimines were synthesized by two methods. Both of these methods are simple and involve a single step, in contrast to the laborious synthesis of stilbenebased polyphenols [31]. However, the first (Method A) which utilizes microwave energy is more environment friendly and consistently gives superior conversions in a shorter reaction time, compared to the traditional method (Method B). All physical and spectral data of the products confirmed the assigned structures and were consistent with the literature data if available [32-34]. Analysis of the aldimine products by gas chromatography-mass spectroscopy (GC-MS), elemental analysis, and NMR spectroscopy indicated that they of high purity (in excess of $99 \%$ ). Analytical and spectral data of all products are shown below.

Hydrolytic stability of these diphenol aldimines in aqueous buffered solutions were evaluated spectrophotometrically at $37^{\circ} \mathrm{C}$. The changes in $\lambda_{\max }$ absorptions (between $315-325 \mathrm{~nm}$ ) were monitored over a period of 24 hours and at $\mathrm{pH}$ ranging from 2.0 to 8.5 . None of these aldimines (except DPA-8 and DPA-9) showed any significant hydrolysis under these conditions. However, DPA-8 and DPA-9 showed 10\% hydrolysis at $\mathrm{pH} 2.0$, but they show no significant hydrolysis between $\mathrm{pH} 7.0$ and $\mathrm{pH} 8.5$.

DPA-1: Yield: $79 \%$ method A, 52\% method B; m.p. $138^{\circ} \mathrm{C}-140^{\circ} \mathrm{C}$ (Lit. $\left.140^{\circ} \mathrm{C}-141^{\circ} \mathrm{C}\right)$. Elemental analysis: (Found: C, 72.98; N, 6.98; calc. for $\mathrm{C}_{13} \mathrm{H}_{11} \mathrm{~N} \mathrm{O}_{2}$ : C, 73.21; $\mathrm{N}, 6.57) .{ }^{1} \mathrm{H}$ NMR $\left(\mathrm{CDCl}_{3}\right): \delta 6.95(2 \mathrm{H}, \mathrm{m}, \mathrm{Ar}-\mathrm{H}), 7.04$ $(1 \mathrm{H}, \mathrm{d}, \mathrm{Ar}-\mathrm{H}), 7.12(2 \mathrm{H}, \mathrm{d}, \mathrm{Ar}-\mathrm{H}), 7.23(1 \mathrm{H}, \mathrm{d}, \mathrm{Ar}-\mathrm{H})$, $7.35(2 \mathrm{H}, \mathrm{d}, \mathrm{Ar}-\mathrm{H}), 8.62(1 \mathrm{H}, \mathrm{s}, \mathrm{N}=\mathrm{CH}) .{ }^{13} \mathrm{C} \mathrm{NMR}$ $\left(\mathrm{CDCl}_{3}\right): \delta 115.1,118.3,122.5,125.3,128.8,131.9$, 135.2, 140.2, 143.9, 148.4, 150.6 .

DPA-2: Yield: $82 \%$ method A, $54 \%$ method B; m.p. $213^{\circ} \mathrm{C}-214^{\circ} \mathrm{C}$ (Lit. $214^{\circ} \mathrm{C}$ ). Elemental analysis: (Found: C, 72.73; N, 6.93; calc. for $\mathrm{C}_{13} \mathrm{H}_{11} \mathrm{~N} \mathrm{O}_{2}: \mathrm{C}, 73.21 ; \mathrm{N}$, 6.57). ${ }^{1} \mathrm{H}$ NMR (acetone-d6): $\delta 6.91(2 \mathrm{H}, \mathrm{d}, \mathrm{Ar}-\mathrm{H}), 7.03$ $(2 \mathrm{H}, \mathrm{d}, \mathrm{Ar}-\mathrm{H}), 7.22(2 \mathrm{H}, \mathrm{d}, \mathrm{Ar}-\mathrm{H}), 7.63(2 \mathrm{H}, \mathrm{d}, \mathrm{Ar}-\mathrm{H})$, $8.56(1 \mathrm{H}, \mathrm{s}, \mathrm{N}=\mathrm{CH}) .{ }^{13} \mathrm{C}$ NMR (acetone-d6): $\delta 113.5$, 119.4, 124.5, 127.3, 129.5, 133.4, 136.8, 141.2, 151.2.

DPA-3: Yield: $85 \%$ method A, 59\% method B; m.p. $194^{\circ} \mathrm{C}-196^{\circ} \mathrm{C}$ (Lit. $\left.197^{\circ} \mathrm{C}-198^{\circ} \mathrm{C}\right)$. Elemental analysis: (Found: C, 72.83; N, 6.79; calc. for $\mathrm{C}_{13} \mathrm{H}_{11} \mathrm{~N} \mathrm{O}_{2}$ : C, 73.21; $\mathrm{N}, 6.57) .{ }^{1} \mathrm{H}$ NMR $\left(\mathrm{CDCl}_{3}\right): \delta 7.01(2 \mathrm{H}, \mathrm{d}, \mathrm{Ar}-\mathrm{H}), 7.18$ (1H, m, Ar-H), $7.32(1 \mathrm{H}, \mathrm{d}, \mathrm{Ar}-\mathrm{H}), 7.43(2 \mathrm{H}, \mathrm{d}, \mathrm{Ar}-\mathrm{H})$, $7.55(1 \mathrm{H}, \mathrm{s}, \mathrm{Ar}-\mathrm{H}), 8.68(1 \mathrm{H}, \mathrm{s}, \mathrm{N}=\mathrm{CH}) .{ }^{13} \mathrm{C}$ NMR $\left(\mathrm{CDCl}_{3}\right): \delta 113.5,117.3,123.8,127.3,130.2,134.3$, 138.2, 143.9, 146.2, 148.4, 152.3 .

DPA-4: Yield: $98 \%$ method A, $65 \%$ method B; m.p. $186^{\circ} \mathrm{C}-187^{\circ} \mathrm{C}$ (Lit. $\left.189^{\circ} \mathrm{C}\right)$. Elemental analysis: (Found: C, 73.12; N, 6.78; calc. for $\mathrm{C}_{13} \mathrm{H}_{11} \mathrm{~N} \mathrm{O}_{2}: \mathrm{C}, 73.21 ; \mathrm{N}$, 6.57). ${ }^{1} \mathrm{H}$ NMR (acetone-d6): $\delta 6.85$ (2H, m, Ar-H), 6.98 $(1 \mathrm{H}, \mathrm{d}, \mathrm{Ar}-\mathrm{H}), 7.06(2 \mathrm{H}, \mathrm{m}, \mathrm{Ar}-\mathrm{H}), 7.13(1 \mathrm{H}, \mathrm{d}, \mathrm{Ar}-\mathrm{H})$, $7.35(1 \mathrm{H}, \mathrm{d}, \mathrm{Ar}-\mathrm{H}), 7.42(1 \mathrm{H}, \mathrm{d}, \mathrm{Ar}-\mathrm{H}), 8.59(1 \mathrm{H}, \mathrm{s}$, $\mathrm{N}=\mathrm{CH}) .{ }^{13} \mathrm{C}$ NMR (acetone-d6): $\delta 113.9,115.3,117.8$, $121.4,123.4,126.8,129.8,133.5,138.1,141.2,146.1$, 151.3, 153.9.

DPA-5: Yield: $87 \%$ method A, $73 \%$ method B; m.p. $127^{\circ} \mathrm{C}-128^{\circ} \mathrm{C}\left(\right.$ Lit. $\left.126^{\circ} \mathrm{C}-128^{\circ} \mathrm{C}\right)$. Elemental analysis: (Found: C, 72.72; N, 6.92; calc. for $\mathrm{C}_{13} \mathrm{H}_{11} \mathrm{~N} \mathrm{O}_{2}$ : C, 73.21; $\mathrm{N}, 6.57) .{ }^{1} \mathrm{H}$ NMR (acetone-d6): $\delta 6.83(2 \mathrm{H}, \mathrm{m}, \mathrm{Ar}-\mathrm{H})$, $6.92(1 \mathrm{H}, \mathrm{d}, \mathrm{Ar}-\mathrm{H}), 7.03(1 \mathrm{H}, \mathrm{m}, \mathrm{Ar}-\mathrm{H}), 7.10(1 \mathrm{H}, \mathrm{d}$, Ar-H), 7.25 ( 1H, d, Ar-H), $7.31(1 \mathrm{H}, \mathrm{s}, \mathrm{Ar}-\mathrm{H}), 7.39(1 \mathrm{H}$, $\mathrm{d}, \mathrm{Ar}-\mathrm{H}), 8.48(1 \mathrm{H}, \mathrm{s}, \mathrm{N}=\mathrm{CH}) .{ }^{13} \mathrm{C}$ NMR (acetone-d6): $\delta$ $112.5,114.9,116.8,122.9,123.6,127.3,130.2,134.2$, $140.2,143.5,146.7,152.3,155.1$.

DPA-6: Yield: $81 \%$ method A, $60 \%$ method B; m.p. 
$124^{\circ} \mathrm{C}-126^{\circ} \mathrm{C}$ (Lit. $128^{\circ} \mathrm{C}$ ). Elemental analysis: (Found: C, 72.75; N, 6.69; calc. for $\mathrm{C}_{13} \mathrm{H}_{11} \mathrm{~N} \mathrm{O}$ : C, 73.21; N, 6.57). ${ }^{1} \mathrm{H}$ NMR (acetone-d6): $\delta 6.78(2 \mathrm{H}, \mathrm{m}, \mathrm{Ar}-\mathrm{H}), 6.88$ $(1 \mathrm{H}, \mathrm{m}, \mathrm{Ar}-\mathrm{H}), 7.08(1 \mathrm{H}, \mathrm{d}, \mathrm{Ar}-\mathrm{H}), 7.18(1 \mathrm{H}, \mathrm{d}, \mathrm{Ar}-\mathrm{H})$, $7.29(1 \mathrm{H}, \mathrm{d}, \mathrm{Ar}-\mathrm{H}), 7.35 .0(1 \mathrm{H}, \mathrm{d}, \mathrm{Ar}-\mathrm{H}), 7.44(1 \mathrm{H}, \mathrm{s}$, Ar-H), $8.56(1 \mathrm{H}, \mathrm{s}, \mathrm{N}=\mathrm{CH}) .{ }^{13} \mathrm{C}$ NMR (acetone-d6): $\delta$ $112.5,116.3,117.9,120.4,123.1,127.2,132.2,134.5$, 139.3, 142.3, 147.9, 152.6, 155.8 .

DPA-7: Yield: $88 \%$ method A, $68 \%$ method B; m.p. $125^{\circ} \mathrm{C}-126^{\circ} \mathrm{C}$. Elemental analysis: (Found: $\mathrm{C}, 72.68 ; \mathrm{N}$, 6.59; calc. for $\left.\mathrm{C}_{13} \mathrm{H}_{11} \mathrm{~N} \mathrm{O}_{2}: \mathrm{C}, 73.21 ; \mathrm{N}, 6.57\right) .{ }^{1} \mathrm{H}$ NMR (acetone-d6): $\delta 6.83(1 \mathrm{H}, \mathrm{dd}, \mathrm{Ar}-\mathrm{H}), 6.90(1 \mathrm{H}, \mathrm{m}, \mathrm{Ar}-\mathrm{H})$, $6.97(1 \mathrm{H}, \mathrm{d}, \mathrm{Ar}-\mathrm{H}), 7.05(1 \mathrm{H}, \mathrm{d}, \mathrm{Ar}-\mathrm{H}), 7.11(1 \mathrm{H}, \mathrm{d}$, Ar-H), $7.18(1 \mathrm{H}, \mathrm{d}, \mathrm{Ar}-\mathrm{H}), 7.25(1 \mathrm{H}, \mathrm{s}, \mathrm{Ar}-\mathrm{H}), 7.32(1 \mathrm{H}, \mathrm{s}$, $\mathrm{Ar}-\mathrm{H}), 7.44(1 \mathrm{H}, \mathrm{s}, \mathrm{Ar}-\mathrm{H}), 8.51(1 \mathrm{H}, \mathrm{s}, \mathrm{N}=\mathrm{CH}) .{ }^{13} \mathrm{C}$ NMR (acetone-d6): $\delta 110.3,117.3,119.3,122.4,125.5,127.6$, $130.1,133.5,137.5,143.3,146.9,151.3,154.7$.

DPA-8: Yield: $53 \%$ method A, 22\% method B; m.p. $140^{\circ} \mathrm{C}-142^{\circ} \mathrm{C}$. Elemental analysis: (Found: C, 60.98; N, 10.35; calc. for $\mathrm{C}_{13} \mathrm{H}_{10} \mathrm{~N} 2 \mathrm{O}_{4}: \mathrm{C}, 60.46 ; \mathrm{N}, 10.85$.) ${ }^{1} \mathrm{H}$ NMR $\left(\mathrm{CDCl}_{3}\right): \delta 6.95(2 \mathrm{H}, \mathrm{m}, \mathrm{Ar}-\mathrm{H}), 7.07(1 \mathrm{H}, \mathrm{d}, \mathrm{Ar}-\mathrm{H})$, $7.14(1 \mathrm{H}, \mathrm{d}, \mathrm{Ar}-\mathrm{H}), 7.22(1 \mathrm{H}, \mathrm{d}, \operatorname{Ar}-\mathrm{H}), 7.33(1 \mathrm{H}, \mathrm{d}$, Ar-H), $7.44(1 \mathrm{H}, \mathrm{s}, \mathrm{Ar}-\mathrm{H}), 8.64(1 \mathrm{H}, \mathrm{s}, \mathrm{N}=\mathrm{CH}) .{ }^{13} \mathrm{C}$ NMR $\left(\mathrm{CDCl}_{3}\right): \delta 111.5,117.6,120.3,122.9,126.3,127.9$, 131.1, 133.6, 137.5, 142.3, 149.2, 151.3, 159.9 .

DPA-9: Yield: $65 \%$ method A, $18 \%$ method B; m.p. $131^{\circ} \mathrm{C}-132^{\circ} \mathrm{C}$. Elemental analysis: (Found: $\mathrm{C}, 60.75 ; \mathrm{N}$, 10.45; calc. for $\mathrm{C}_{13} \mathrm{H}_{10} \mathrm{~N} 2 \mathrm{O}_{4}: \mathrm{C}, 60.46 ; \mathrm{N}, 10.85$.) ${ }^{1} \mathrm{H}$ NMR $\left(\mathrm{CDCl}_{3}\right): \delta 6.90(2 \mathrm{H}, \mathrm{m}, \mathrm{Ar}-\mathrm{H}), 7.04(1 \mathrm{H}, \mathrm{d}, \mathrm{Ar}-\mathrm{H})$, $7.11(1 \mathrm{H}, \mathrm{d}, \mathrm{Ar}-\mathrm{H}), 7.23(1 \mathrm{H}, \mathrm{d}, \mathrm{Ar}-\mathrm{H}), 7.36(1 \mathrm{H}, \mathrm{d}$, Ar-H), $7.48(1 \mathrm{H}, \mathrm{s}, \mathrm{Ar}-\mathrm{H}), 8.59(1 \mathrm{H}, \mathrm{s}, \mathrm{N}=\mathrm{CH}) .{ }^{13} \mathrm{C}$ NMR $\left(\mathrm{CDCl}_{3}\right): \delta 112.3,115.6,119.6,123.9,125.2,128.9$, $131.1,134.5,138.5,144.5,148.9,150.5,158.3$.

\subsection{Biological Tests}

Inhibition studies of ATPase showed that the potencies of aldimines depend on the relative positioning of the phenolic-OH groups. The least inhibiting aldimine (DPA-2), with both -OH groups in the para-positions, is the only one of these compounds that is found to be less potent than the natural polyphenols. All other aldimines exhibited superior inhibition capability compared to both resveratrol and piceatannol, with $\mathrm{IC}_{50}$ values ranging between $2 \mu \mathrm{M}$ and $9 \mu \mathrm{M}$ (Table 1). This indicates that the presence of both the imino and hydroxyl groups in these compounds may play favorable roles in the binding of the inhibitor to the enzyme. The presence of an electron-withdrawing substituent such as a nitro group appears to have no significant effect on the inhibitory potency (DPA-8 and DPA-9 vs. DPA-1 and DPA-4, respectively). Mutagenesis studies involving bovine ATPase have previously shown that the inhibition by natural polyphenols such as resveratrol, quercetin, and picea- tannol could be attributed to their ability to interfere with the rotary mechanism of the enzyme [23]. Presumably the interaction between the DPA compounds and the enzyme, and their inhibitory mechanisms, are similar to that of the natural polyphenols.

Some of these DPA compounds (DPA-1, DPA-3, DPA-7, DPA-8 and DPA-9) inhibit the enzyme completely, while others cause only partial inhibition (DPA-2, DPA-4, DPA-5, and DPA-6), even when using concentrations beyond the saturation point (Figure 1). In all cases, however, inhibition of the enzyme by DPAs was completely reversible. It is unclear whether the inhibitors bind to the active site of the enzyme or to other domains. Among all the DPA compounds studies only DPA-2 showed weak inhibitory effect $\left(20 \%\right.$ inhibition, $\mathrm{IC}_{50}=$ $100 \mu \mathrm{M})$, which is comparable to that of resveratrol ( $40 \%$ inhibition, $\mathrm{IC}_{50}=94 \mu \mathrm{M}$ ). It is not clear at this point if the paraphenolic $\mathrm{OH}$ group (which exists in both DPA-2 and resveratrol) caused that low activity. Further study, including kinetic analysis, is underway in attempt to understand and to explain these observations.

Study of $E$. coli cell growth pattern in the presence of DPA inhibitors (Table 1) showed that loss of growth was symbatic to the extent of ATP synthase inhibition. Inhibition of cell growth generally could be attributed in part to inhibition of oxidative phosphorylation, glycolysis, or both. Data show that all DPA compounds (except DPA-2)

Table 1. Inhibition of E. coli ATP synthase activity and cell growth by diphenol aldimine compounds.

\begin{tabular}{|c|c|c|c|}
\hline Compound & ${ }^{\mathrm{a}} \mathrm{IC}_{50}(\mu \mathrm{M})$ & $\begin{array}{l}{ }^{\mathrm{b}} \text { Growth on } \\
\text { succinate plate }\end{array}$ & $\begin{array}{c}{ }^{\mathrm{c}} \text { Growth on } \\
\text { limiting glucose }(\%)\end{array}$ \\
\hline DPA-1 & 5 & - & 42 \\
\hline DPA-2 & 100 & + & 84 \\
\hline DPA-3 & 9 & - & 46 \\
\hline DPA-4 & 7 & - & 43 \\
\hline DPA-5 & 9 & - & 53 \\
\hline DPA-6 & 5 & - & 51 \\
\hline DPA-7 & 2 & - & 44 \\
\hline DPA-8 & 6 & - & 44 \\
\hline DPA-9 & 5 & - & 47 \\
\hline Resveratrol $^{d}$ & 94 & - & 42 \\
\hline Piceatannol $^{\mathrm{d}}$ & 14 & - & 43 \\
\hline Wild starin $^{\mathrm{c}}$ & & + & 100 \\
\hline Null $^{\mathrm{f}}$ & & - & 45 \\
\hline
\end{tabular}

${ }^{\mathrm{a}} \mathrm{IC}_{50}$ : concentration of inhibitor at $50 \%$ of maximal inhibition; ${ }^{\mathrm{b}} \mathrm{Growth}$ on succinate: positive growth $(+) ;(-)$ no growth; ${ }^{\mathrm{C}}$ Growth on limiting glucose: $\%$ relative to uninhibited growth; ${ }^{\mathrm{d}}$ From reference [25]; ${ }^{\mathrm{e}}$ Control, E. coil. wild strain pBWU13.4/DK8; ${ }^{\mathrm{f}}$ Null strain, E. coil. Puc118/dk8. 

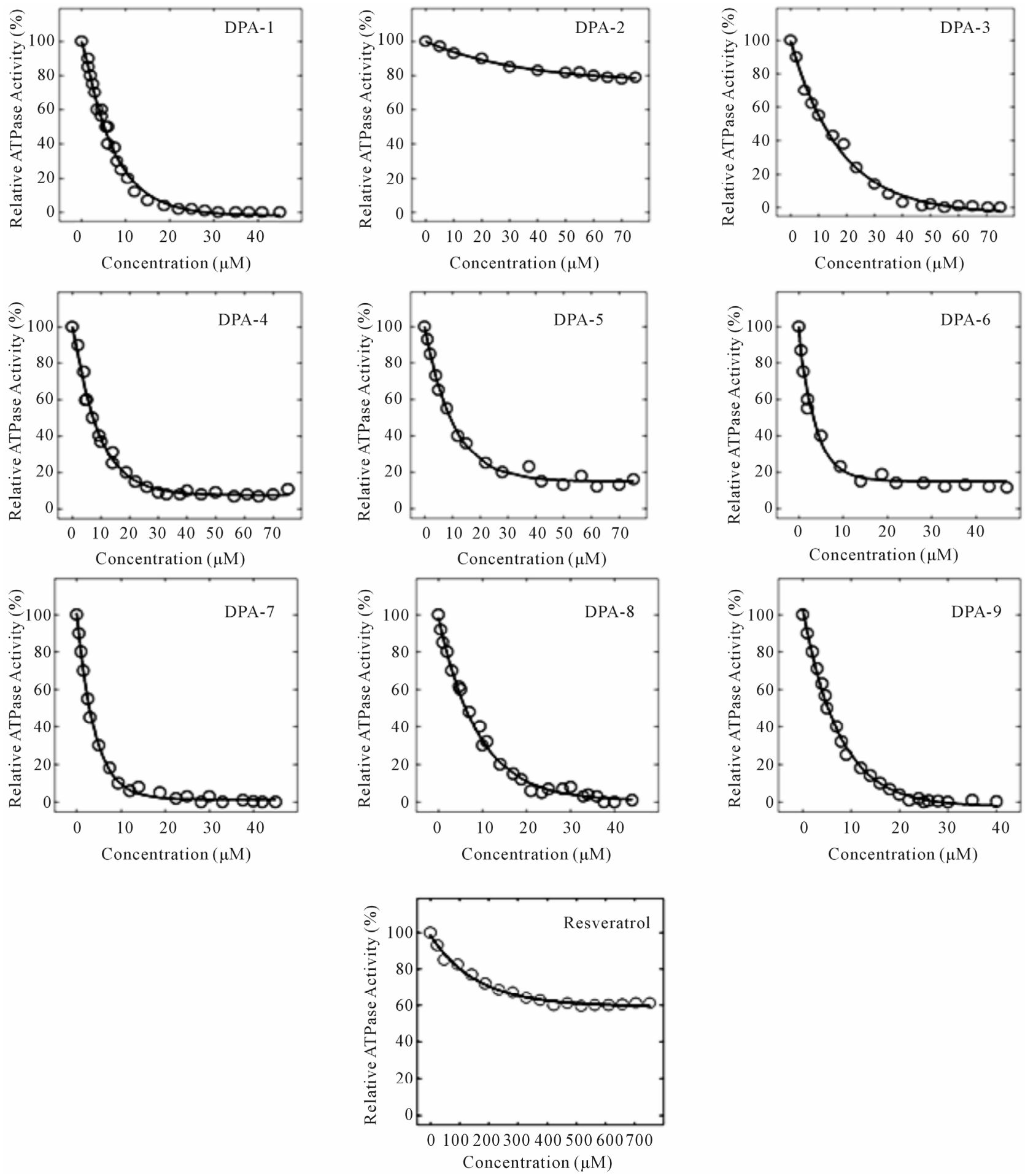

Figure 1. Inhibition curves of $E$. coli (wild strain pBWU13.4/DK8) $\mathrm{F}_{1}$ ATP synthase $(1.0 \mathrm{mg} / \mathrm{mL}$ ) by diphenol aldimines (DPA), at $37^{\circ} \mathrm{C}$ and $\mathrm{pH} 8.0$ for 1 hour.

inhibit only oxidative phosphorylation but not glycolysis. At this time we cannot determine for sure whether growth inhibition was only due to inhibition of ATP synthase or it involves also inhibition of other respiratory pathways. Future work involving study of the effects of these compounds on respiration of bacteria or bacterial enriched membranes would give some insight in this respect. On the other hand earlier studies have shown that natural polyphenols like quercetin, quercetin-3- $\beta$ glucoside, and the antibiotic Venturicidin, all inhibit ATP 
synthesis but not cell growth $[24,35]$.

\section{CONCLUSION}

In our continuing effort to identify potent inhibitors of ATP synthase, we synthesized a series of diphenol aldimine analogs of the natural polyphenols and studied their effects on the enzyme inhibition. The fact that these DPA compounds can inhibit both ATP synthesis and cell growth, unlike the natural polyphenols, is promising and it indicates that they may have unique and therapeutically significant applications. Currently we are performing mutagenic analysis of the ATPase binding site to understand the effect of the phenolic $\mathrm{OH}$ groups and their relative positions on their inhibitory potencies. Future work also will include synthesis of a larger combinatorial library of these PDA compounds, and testing of their inhibitory effects on mammalian ATP synthase and other ATP-dependent enzymes to assess their specificity.

\section{ACKNOWLEDGEMENTS}

This work was supported in part by the National Institutes of Health Grant (GM085771) to ZA, and by institutional support from East Tennessee State University Student-Faculty Collaboration Award to JE and IK.

\section{REFERENCES}

[1] Hong, S. and Pedersen, P.L. (2008) ATP synthase and the actions of inhibitors utilized to study its roles in human health, disease, and other scientific areas. Microbiology Molecular Biology Reviews, 72, 590-641. doi:10.1128/MMBR.00016-08

[2] Noji, H. and Yoshida, M. (2001) The rotary machine in the cell, ATP synthase. Journal of Biological Chemistry, 276, 1665-1668. doi:10.1074/jbc.R000021200

[3] Weber, J. and Senior, J.A.E. (2003) Synthesis driven by proton transport in $\mathrm{F}_{1} \mathrm{~F}_{0}$-ATP synthase. FEBS Letters, $\mathbf{5 4 5}$, 61-70. doi:10.1016/S0014-5793(03)00394-6

[4] Ahmad, Z. and Laughlin, T.F. (2010) Medicinal chemistry of ATP synthase: A potential drug target of dietary polyphenols and amphibian antimicrobial peptides. Current Medicinal Chemistry, 17, 2822-2836.

[5] Arakaki, N., Nagao, T., Niki, R., Toyofuku, A., Tanaka, H., Kuramoto, Y., Emoto, Y., Shibata, H., Magota, K. and Higuti, T. (2003) Possible role of cell surface $\mathrm{H}^{+}$-ATP synthase in the extracellular ATP synthesis and proliferation of human umbilical vein endothelial cells. Molecular Cancer Research, 1, 931-939.

[6] Martinez, L.O., Jacquet, S., Esteve, J.P., Rolland, C., Cabezon, E., Champagne, E., Pineau, T., Georgeaud, V., Walker, J.E., Terce, F., Collet, X., Perret, B. and Barbaras, R. (2003) Ectopic beta-chain of ATP synthase is an apolipoprotein A-I receptor in hepatic HDL endocytosis. $\mathrm{Na}$ ture, 421, 75-79. doi:10.1038/nature01250

[7] Chang, S.Y., Park, S.G., Kim, S. and Kang, C.Y. (2002)
Interaction of the C-terminal domain of p43 and the alpha subunit of ATP synthase and its functional implication in endothelial cell proliferation. The Journal of Biological Chemistry, 277, 8388-8394. doi:10.1074/jbc.M108792200

[8] Scotet, E., Martinez, L.O., Grant, E., Barbaras, R., Jeno, P., Guiraud, M., Monsarrat, B., Saulquin, X., Maillet, S., Esteve, J. P., Lopez, F., Perret, B., Collet, X., Bonneville, M. and Champagne, E. (2005) Tumor recognition following Vgamma9Vdelta2 $\mathrm{T}$ cell receptor interactions with a surface $\mathrm{F}_{1}$-ATPase-related structure and apolipoprotein A-I. Immunity, 22, 71-80. doi:10.1016/j.immuni.2004.11.012

[9] Burwick, N.R., Wahl, M.L., Fang, J., Zhong, Z., Moser, T.L., Li, B., Capaldi, R.A., Kenan, D.J. and Pizzo, S.V. (2005) An inhibitor of the F1 subunit of ATP synthase (IF1) modulates the activity of Angiostatin on the endothelial cell surface. Journal of Biological Chemistry, 280, 17401745. doi:10.1074/jbc.M405947200

[10] Moser, T.L., Kenan, D.J., Ashley, T.A., Roy, J.A., Goodman, M.D. and Misra, U.K. (2000) Endothelial cell surface F1-F0 ATP synthase is active in ATP synthesis and is inhibited by angiostatin. PNAS, 98, 6656-6661. doi:10.1073/pnas. 131067798

[11] Huang, T.-C., Chang, H.-Y., Hsu, C.-H., Kuo, W.-H., Chang, K.-J. and Juan, H.-F. (2008) Targeting therapy for breast carcinoma by ATP synthase inhibitor Aurovertin B. Journal of Proteome Research, 7, 1433-1444. doi:10.1021/pr700742h

[12] Chi, S.L. and Pizzo, S.V. (2006) Angiostatin is directly cytotoxic to tumor cells at low extracellular $\mathrm{pH}$ : A mechanism dependent on cell surface-associated ATP syMnthase. Cancer Research, 66, 875-882. doi:10.1158/0008-5472.CAN-05-2806

[13] Kim, B.W., Choo, H.J., Lee, J.W., Kim, J.H. and Ko, Y.G., (2004) Extracellular ATP is generated by ATP synthase complex in adipocyte lipid rafts. Experimental and $\mathrm{Mo}-$ lecular Medicine, 36, 476-485.

[14] Arakaki, N., Nagao, T., Niki, R., Toyofuku, A., Tanaka, H., Kuramoto, Y., Emoto, Y., Shibata, H., Magota, K. and Higuti, T. (2003) Possible role of cell surface $\mathrm{H}^{+}$-ATP synthase in the extracellular ATP synthesis and proliferation of human umbilical vein endothelial cells. Molecular Cancer Research, 1, 931-939.

[15] Johnson, K.M., Cleary, J., Fierke, C.A., Opipari, A.W. and Glick, G.D. (2006) Mechanistic basis for therapeutic targeting of the mitochondrial $\mathrm{F}_{1} \mathrm{~F}_{0}$-ATPase. ACS Chemical Biology, 1, 304-308. doi:10.1021/cb600143j

[16] Moreno-Sa'nchez, R., Rodri'guez-Enrı'quez, S., Marı'nHerna'ndez, A. and Saavedra, E. (2007) Energy metabolism in tumor cells. FEBS Journal, 274, 1393-1418. doi:10.1111/j.1742-4658.2007.05686.x

[17] Toogood, P.L. (2008) Mitochondrial drugs. Current Opinion in Chemical Biology, 12, 457-463. doi:10.1016/j.cbpa.2008.06.002

[18] Duarte, S., Gregoire, S., Singh, A.P., Vorsa, N., Schaich, K., Bowen, W.H. and Koo, H. (2006) Inhibitory effects of cranberry polyphenols on formation and acidogenicity of Streptococcus mutans biofilms. FEMS Microbiology Let- 
ters, 257, 50-56. doi:10.1111/j.1574-6968.2006.00147.x

[19] Percival, R.S., Devine, D.A., Duggal, M.S., Chartron, S. and Marsh, P.D. (2006) The effect of cocoa polyphenols on the growth, metabolism, and biofilm formation by Streptococcus mutans and Streptococcus sanguinis. European Journal of Oral Sciences, 114, 343-348. doi:10.1111/j.1600-0722.2006.00386.x

[20] Anderies, K., Verhasselt, P., Guillemont, J., Gohlmann, H.W.H., Neefs, J.M., Winkler, H., Gestel, J.F., Timmerman, P., Zhu, M., Lee, E., Williams, P., Chaffoy, D.D., Huitric, E., Hoffner, S., Cambau, E., Truffot-Pernot, C., Lounis, N. and Jarlier, V. (2005) A diarylquinoline drug active on the ATP synthase of mycobacterium tuberculosis. Science, 307, 223-227. doi:10.1126/science. 1106753

[21] Barta, I., Smerak, P., Polivkova, Z., Sestakova, H., Langova, M., Turek, B. and Bartova, J. (2006) Current trends and perspectives in nutrition and cancer prevention. $\mathrm{NeO}-$ plasma, 53, 19-25.

[22] Nishino, H., Murakoshi, M., Mou, X.-Y., Wada, S., Masuda, M., Ohsaka, Y., Satomi, Y. and Jinno, K. (2005) Cancer prevention by phytochemicals. Oncology, 69, 3840. doi:10.1159/000086631

[23] Gledhill, J.R., Montgomery, M.G.., Leslie, A.G.W. and Walker, J.W. (2007) Mechanism of inhibition of bovine F1-ATPase by resveratrol and related polyphenols. Proceedings of the National Academy of Sciences USA, 104, 13632-13637. doi:10.1073/pnas.0706290104

[24] Chinnam, N., Dadi, P.K., Sabri, S.A., Ahmad, M., Kabir, M.A. and Ahmad, Z. (2010) Role of charged residues in the catalytic sites of Escherichia coli ATP synthase. International Journal of Biological Macromolecules, 46, 478-486. doi:10.1016/j.ijbiomac.2010.03.009

[25] Dadi, P.K., Ahmad, M. and Ahmad, Z. (2009) Inhibition of ATPase activity of Escherichia coli ATP synthase by polyphenols. International Journal of Biological Macromolecules, 45, 72-79. doi:10.1016/j.ijbiomac.2009.04.004

[26] Zheng, J. and Ramirez, V.D. (2000) Inhibition of mitochondrial proton F0F1-ATPase/ATP synthase by polyphenolic phytochemicals. British Journal of Pharmacology, 130, 1115-1123. doi:10.1038/sj.bjp.0703397
[27] Ketchum, C.J., Al-Shawi, M.K. and Nakamoto, R.K. (1998) Intergenic suppression of the gammaM23K uncoupling mutation in $\mathrm{F}_{0} \mathrm{~F}_{1}$ ATP synthase by betaGlu-381 substitutions: The role of the beta ${ }^{380}$ DELSEED $^{386}$ segment in energy coupling. Biochemical Journal, 330, $707-$ 712.

[28] Weber, J., Lee, R.S.F., Grell, E., Wise, J.G. and Senior, A.E. (1992) On the location and function of tyrosine beta 331 in the catalytic site of Escherichia coli F1-ATPase. Journal of Biological Chemistry, 267, 1712-1718.

[29] Taussky, H.H. and Shorr, E. (1953) A microcolorimetric method for the determination of inorganic phosphate. Journal of Biological Chemistry, 202, 675-685.

[30] Senior, A.E., Latchney, L.R., Ferguson, A.M. and Wise, J.G. (1984) Purification of $F_{1}$-ATPase with impaired catalytic activity from partial revertants of Escherichia coliuncA mutant strains. Archives of Biochemistry and Biophysics, 228, 49-53. doi:10.1016/0003-9861(84)90045-6

[31] Sun, H.-Y., Xiao, C.-F., Cai, Y.-C., Chen, Y., Wei, W., Liu, X.-K., Lv, Z.-L. and Zou, Y. (2010) Efficient synthesis of natural polyphenolic stilbenes: Resveratrol, piceatannol and oxyresveratrol. Chemical and Pharmaceutical Bulletin, 58, 1492-1496. doi:10.1248/cpb.58.1492

[32] Solomon, K.R.H., Lieberman, H.E., Groundwater, P.W., Hibbs, D.E. and Hursthouse, M. (1997) Molecular modeling and biological evaluation of a series of hydroxylated benzylideneanilines and benzylamines designed as tyrosine kinase inhibitors. Anti-Cancer Drug Design, 12, 635-647.

[33] Bigelow, L.A. and Gatough, H. (1941) Benzalpinacolone. Organic Synthesis Collective, 1, 81.

[34] Ibrahim, H.N. and Al-Deeb, H.K. (2006) Synthesis, characterization and study of the biological activity of some aldimines derivatives. E-Journal of Chemistry, 3, 257-261. doi: $10.1155 / 2006 / 618718$

[35] Perlin, D.S., Latchney, L.R. and Senior, A.E. (1985) Inhibition of Escherichia coli $\mathrm{H}^{+}$-ATPase by venturicidin, oligomycin and ossamycin. Biochimica Biophysica Acta, 807, 238-244. doi:10.1016/0005-2728(85)90254-3 